\title{
Short communication: Effects of molasses products on productivity and milk fatty acid profile of cows fed diets high in dried distillers grains with solubles ${ }^{1}$
}

\author{
A. Siverson, C. F. Vargas-Rodriguez, and B. J. Bradford ${ }^{2}$ \\ Department of Animal Sciences and Industry, Kansas State University, Manhattan 66506
}

\begin{abstract}
Previous research has shown that replacing up to 5\% [of dietary dry matter (DM)] corn with cane molasses can partially alleviate milk fat depression when cows are fed high-concentrate, low-fiber rations containing dried distillers grains with solubles. The primary objective of this study was to determine whether dietary molasses alters milk fatty acid (FA) profile or improves solids-corrected milk yield in the context of a more typical lactation diet. A secondary objective was to assess production responses to increasing rumen-degradable protein supply when molasses was fed. Twelve primiparous and 28 multiparous Holstein cows $(196 \pm 39 \mathrm{~d}$ in milk) were blocked by parity and assigned to 4 pens. Pens were randomly allocated to treatment sequence in a $4 \times 4$ Latin square design, balanced for carryover effects. Treatment periods were $21 \mathrm{~d}$, with $17 \mathrm{~d}$ for diet adaptation and $4 \mathrm{~d}$ for sample and data collection. Treatments were a control diet, providing $20 \%$ dried distillers grains with solubles (DM basis), 35\% neutral detergent fiber, $30 \%$ starch, and 5\% ether extract; a diet with $4.4 \%$ cane molasses replacing a portion of the corn grain; a diet with $2.9 \%$ molasses supplement containing $32 \%$ crude protein on a DM basis; and a diet with $5.8 \%$ (DM basis) molasses supplement. Animallevel data were analyzed using mixed models, including the fixed effect of treatment and the random effects of period, pen, period $\times$ pen interaction, and cow within pen to recognize pen as the experimental unit. Diets did not alter DM intake, milk production, milk component concentration or yield, feed efficiency (DM intake/milk yield), body weight change, or milk somatic cell count. Milk stearic acid content was increased by the diet containing $5.8 \%$ molasses supplement compared with the control diet and the diet containing $2.9 \%$ molasses supplement, but the magnitude of the effect was small $(12.27,11.75$, and $11.69 \pm 0.29 \mathrm{~g} / 100 \mathrm{~g}$ of FA). Production data revealed a dramatic effect of period on milk
\end{abstract}

\footnotetext{
Received January 5, 2014.

Accepted March 7, 2014.

${ }^{1}$ Contribution no. 14-183-J from the Kansas Agricultural Experiment Station.

${ }^{2}$ Corresponding author: bbradfor@ksu.edu
}

fat content and yield. Milk fat content decreased during the course of the experiment (least squares means $=$ $3.16,2.81,2.93$, and $2.64 \pm 0.09 \%$ for periods 1 to 4 , respectively), as did milk fat yield $(1.20,1.03,0.98$, and $0.79 \pm 0.05 \mathrm{~kg} / \mathrm{d})$. Exchanging molasses-based products for corn at 2.9 to $5.8 \%$ of dietary DM did not influence productivity and had minute effects on milk FA profile. The limited responses in this study may have been influenced by dietary unsaturated FA content or the advancing stage of lactation of cows in the study.

Key words: biohydrogenation, milk fat depression, sugar

\section{Short Communication}

Dried distillers grains with solubles (DDGS) have acquired relevance as a feedstuff for the dairy industry due to their highly digestible NDF fraction with low lignin content (NRC, 2001; Getachew et al., 2004). In addition, DDGS are considered an excellent source of RUP (Santos et al., 1998) and are used as an alternative energy source to replace feeds such as corn and soybean meal (Powers et al., 1995). The resulting decrease in dietary starch content can help minimize the incidence of rumen acidosis (Kleinschmit et al., 2006). Inclusion of DDGS is often limited to $10 \%$ of DM (Hollmann et al., 2011), despite some references (Janicek et al., 2008; Ranathunga et al., 2010) demonstrating success in proportions up to $30 \%$ of DM. The primary limitation is the high unsaturated fat content in DDGS (SasikalaAppukuttan et al., 2008), which can be detrimental from a milk fat production standpoint (Hollmann et al., 2011). Recent research (Martel et al., 2011) has demonstrated that replacing corn with cane molasses at up to $5.0 \%$ of diet DM can partially alleviate milk fat depression (MFD) when cows are fed high-concentrate, low-fiber rations containing DDGS; however, this change also decreased milk protein and lactose yields, resulting in no improvement in SCM yield. The diets used by Martel et al. (2011) were extremely low in fiber and high in starch, with the goal of ensuring that MFD occurred in the control treatment. The main objective of the present study was to determine whether molasses products would alter the milk FA profile or improve 
ECM yield in the context of a more typical lactation diet. A secondary objective was to assess production responses to increasing RDP supply when molasses was fed to lactating dairy cows.

The Kansas State University Institutional Animal Care and Use Committee approved all experimental procedures. Forty Holstein cows (12 primiparous and 28 multiparous; $196 \pm 39$ DIM) from the Kansas State University Dairy Cattle Teaching and Research Unit (Manhattan) were stratified by parity (primiparous vs. multiparous) and milk fat concentration on the previous DHIA test day. Within strata, cows were randomly assigned to 1 of 4 pens (10 cows/pen; 7 multiparous and 3 primiparous), and pens were randomly assigned to a treatment sequence in a $4 \times 4$ Latin square design, balanced for carryover effects. Treatments were designed to contain between 2.5 and $5.0 \%$ molasses (DM basis) to potentially alleviate MFD (Martel et al., 2011). Treatments were a control (CON) diet, including (on a DM basis) 20\% DDGS, 35\% NDF, 30\% starch, and $5 \%$ ether extract; a diet with $4.4 \%$ cane molasses replacing a portion of ground corn grain (MOL); a diet with 2.9\% molasses supplement (MS3; Dairy TMR 20;
Quality Liquid Feeds, Dodgeville, WI); and a diet with $5.8 \%$ of the same molasses supplement (MS6). Each diet (Table 1) was formulated to meet NRC (2001) requirements for all nutrients for cows of $645-\mathrm{kg} \mathrm{BW}$ producing $45 \mathrm{~kg}$ of milk/d with $3.5 \%$ milk fat and $3.3 \%$ milk protein. Corn silage DM was determined twice weekly to adjust its inclusion rate. Rations were delivered as TMR, and cows were fed once daily $(630 \mathrm{~h})$ for ad libitum intake and milked 3 times daily $(0600,1300$, and $2000 \mathrm{~h}$ ) throughout the experiment. Treatment periods were $21 \mathrm{~d}$, with $17 \mathrm{~d}$ for diet adaptation and $4 \mathrm{~d}$ for sample and data collection, and the study was conducted between April 16 and July 8, 2009.

During the final $4 \mathrm{~d}$ of each period, feed offered and refused were measured for each pen daily to determine feed intake. Samples of TMR and each feed ingredient were collected daily and stored frozen. Samples were composited by period, dried in a $55^{\circ} \mathrm{C}$ forced-air oven for $48 \mathrm{~h}$, and ground through a 1-mm screen (Wiley mill; Arthur H. Thomas Co., Swedesboro, NJ) before analysis of DM, CP, NDF, crude fat, and starch (Dairy One Laboratories, Ithaca, NY). Samples were dried in a forced-air oven for $16 \mathrm{~h}$ at $105^{\circ} \mathrm{C}$ to determine

Table 1. Ingredient and nutrient composition of diets

\begin{tabular}{|c|c|c|c|c|}
\hline \multirow[b]{2}{*}{ Item } & \multicolumn{4}{|c|}{ Treatment $^{1}$} \\
\hline & $\mathrm{CON}$ & MOL & MS3 & MS6 \\
\hline \multicolumn{5}{|l|}{ Ingredient $^{2}$} \\
\hline Corn silage & 45.6 & 45.6 & 45.6 & 45.6 \\
\hline Alfalfa hay & 9.2 & 9.2 & 9.2 & 9.2 \\
\hline Corn DDGS ${ }^{3}$ & 20.1 & 20.0 & 19.9 & 20.1 \\
\hline Ground corn grain & 14.8 & 10.7 & 13.5 & 12.2 \\
\hline Soybean hulls & 2.5 & 1.5 & 2.5 & 2.5 \\
\hline Cane molasses & & 4.4 & & \\
\hline Molasses supplement ${ }^{4}$ & & & 2.9 & 5.8 \\
\hline Soybean meal & 3.0 & 3.8 & 1.5 & \\
\hline Expeller soybean meal $^{5}$ & 3.0 & 3.0 & 3.0 & 3.0 \\
\hline Limestone & 0.82 & 0.81 & 0.81 & 0.82 \\
\hline Trace mineral salt & 0.35 & 0.35 & 0.35 & 0.35 \\
\hline Micronutrient premixes ${ }^{6}$ & 0.16 & 0.16 & 0.16 & 0.16 \\
\hline \multicolumn{5}{|l|}{ Nutrient $^{2}$} \\
\hline DM (\%, as fed) & 57.7 & 57.1 & 57.0 & 56.8 \\
\hline $\mathrm{CP}$ & 16.3 & 17.0 & 16.4 & 16.8 \\
\hline $\mathrm{RDP}^{7}$ (\% of $\mathrm{CP}$ ) & 60.2 & 60.8 & 61.8 & 63.4 \\
\hline NDF & 34.6 & 33.4 & 33.4 & 32.9 \\
\hline Starch & 29.5 & 24.8 & 28.0 & 26.3 \\
\hline Ether extract & 5.0 & 4.9 & 4.8 & 4.8 \\
\hline $\mathrm{NE}_{\mathrm{L}}^{7}(\mathrm{Mcal} / \mathrm{kg})$ & 1.81 & 1.81 & 1.79 & 1.81 \\
\hline \multicolumn{5}{|c|}{$\begin{array}{l}{ }^{1} \mathrm{CON}=\text { control; } \mathrm{MOL}=4.4 \% \text { molasses replacing corn; } \mathrm{MS} 3=2.9 \% \text { molasses product replacing corn; MS6 }= \\
5.8 \% \text { molasses product replacing corn. }\end{array}$} \\
\hline \multicolumn{5}{|c|}{${ }^{2}$ Values are expressed as a percentage of diet DM, unless otherwise specified. } \\
\hline \multicolumn{5}{|c|}{${ }^{3}$ DDGS $=$ dried distillers grains with solubles. } \\
\hline \multicolumn{5}{|c|}{${ }^{4}$ Dairy TMR 20 (Quality Liquid Feeds, Dodgeville, WI). } \\
\hline \multicolumn{5}{|c|}{${ }^{5}$ Soy Best (Grain States Soya Inc., West Point, NE). } \\
\hline \multirow{2}{*}{\multicolumn{5}{|c|}{$\begin{array}{l}{ }^{6} \text { Premix consisted of } 26.1 \% \text { magnesium oxide, } 22.4 \% \text { selenium premix ( } 600 \mathrm{mg} \text { of Se } / \mathrm{kg} \text { ), } 25.8 \% \text { 4-Plex (Zinpro } \\
\text { Corp., Eden Prairie, MN), } 17.2 \% \text { vitamin E premix (44 IU/g), } 6.9 \% \text { vitamin A premix }(30 \mathrm{IU} / \mathrm{g} \text { ), and } 1.7 \% \\
\text { vitamin D premix ( } 30 \mathrm{IU} / \mathrm{g}) \text {. }\end{array}$}} \\
\hline & & & & \\
\hline${ }^{7}$ Predicted according to $\mathrm{Nl}$ & & & & \\
\hline
\end{tabular}


Table 2. Nutrient composition of the liquid supplements

\begin{tabular}{lcc}
\hline Nutrient $^{1}$ & Molasses & $\begin{array}{c}\text { Molasses } \\
\text { product }^{2}\end{array}$ \\
\hline $\mathrm{DM}(\%$, as fed) & 70.9 & 65.5 \\
$\mathrm{CP}$ & 9.9 & 32.1 \\
$\mathrm{CP}$ from NPN & & 19.9 \\
Calcium & 0.4 & 0.90 \\
Phosphorus & 1.27 & 0.64 \\
Potassium & 0.08 & 4.84 \\
Total sugar by invertase $^{4}$ & 5.95 & 51.6 \\
\hline
\end{tabular}

${ }^{1}$ Values are expressed as a percentage of diet DM.

${ }^{2}$ Dairy TMR 20 (Quality Liquid Feeds, Dodgeville, WI).

${ }^{3}$ Nonprotein nitrogen from urea.

${ }^{4}$ Lane and Eynon (1923).

DM content. The concentration of ash was determined after $4 \mathrm{~h}$ of combustion at $500^{\circ} \mathrm{C}$ in a muffle furnace. Nitrogen content was determined by combustion and detection of $\mathrm{N}_{2}$ (Leco Analyzer; Leco Corp., St. Joseph, $\mathrm{MI})$. Concentration of NDF was determined using an Ankom Fiber Analyzer (Ankom Technology Corp., Fairport, NY), including amylase and sodium sulfite (Van Soest et al., 1991). Crude fat was determined by ether extraction (AOAC International, 2000; method 920.9). Dietary $\mathrm{NE}_{\mathrm{L}}$ content was estimated according to NRC (2001) at $3 \times$ maintenance intake.

Milk yield was recorded and milk samples were collected at each milking. Additional samples were collected for each cow at each milking on d 21 of each period, composited, and stored at $-20^{\circ} \mathrm{C}$ until analysis for FA profile. Milk samples were composited by day and analyzed for concentrations of fat, lactose, true protein (B-2000 Infrared Analyzer; Bentley Instruments Inc.,
Chaska, MN), urea nitrogen (MUN spectrophotometer; Bentley Instruments Inc.), and SCC (SCC 500; Bentley Instruments Inc.; Heart of America DHIA, Manhattan, KS). For FA analysis, milk samples were thawed, shaken, and lyophilized. The lyophilized samples were resuspended in $1 \mathrm{~mL}$ of hexane containing $\mathrm{C} 13: 0$ as an internal standard and methylated using $\mathrm{BF}_{3}$-methanol. The resulting FAME were extracted in hexane and injected onto a Supelco SP-2560 capillary GC column (Supelco Inc., Bellefonte, PA) for FA profile analysis (Martel et al., 2011).

Feed intake data for each pen were divided by the number of cows in that pen on that day. All data were analyzed with PROC MIXED of SAS (version 9.2; SAS Institute Inc., Cary, NC) using the fixed effect of treatment and the random effects of period and pen. Milk data also included the random effects of cow nested within pen and pen $\times$ period to provide the error term for the pen-level analysis. Denominator degrees of freedom were approximately 6 for all the treatments tests, verifying that pen was treated as the experimental unit for all variables. Random effects means for periods were noted to differ substantially for milk fat content and, as a result, a second round of analysis was conducted to explore the significance of the fixed effect of period for milk fat content, yield, and milk FA profile; the model was otherwise identical to that detailed above. Significance was declared at $P<0.05$ and tendencies at $0.05 \leq P<0.10$.

The ingredient and nutrient composition of treatments are detailed in Table 1, and molasses ingredient analyses in Table 2. Diets were similar across treat-

Table 3. Effects of treatments on performance of lactating cows

\begin{tabular}{|c|c|c|c|c|c|c|}
\hline \multirow[b]{2}{*}{ Item } & \multicolumn{4}{|c|}{ Treatment $^{1}$} & \multirow[b]{2}{*}{ SEM } & \multirow[b]{2}{*}{$P$-value } \\
\hline & $\mathrm{CON}$ & MOL & MS3 & MS6 & & \\
\hline DMI $(\mathrm{kg} / \mathrm{d})$ & 22.3 & 21.9 & 21.9 & 22.8 & 1.1 & 0.35 \\
\hline Milk yield $(\mathrm{kg} / \mathrm{d})$ & 34.8 & 34.9 & 34.3 & 34.4 & 1.8 & 0.92 \\
\hline Milk fat $(\%)$ & 2.82 & 2.90 & 2.86 & 2.99 & 0.12 & 0.13 \\
\hline Milk protein (\%) & 3.24 & 3.21 & 3.21 & 3.21 & 0.03 & 0.89 \\
\hline Milk lactose (\%) & 4.92 & 4.91 & 4.92 & 4.94 & 0.03 & 0.71 \\
\hline MUN (mg/dL) & 12.1 & 12.2 & 11.6 & 12.6 & 1.00 & 0.23 \\
\hline $\mathrm{SCC}(\times 1,000 / \mathrm{mL})$ & 236 & 184 & 164 & 148 & 53.0 & 0.47 \\
\hline Fat yield $(\mathrm{kg} / \mathrm{d})$ & 0.98 & 1.02 & 0.98 & 1.03 & 0.09 & 0.42 \\
\hline Protein yield (kg/d) & 1.12 & 1.11 & 1.09 & 1.10 & 0.05 & 0.59 \\
\hline Lactose $(\mathrm{kg} / \mathrm{d})$ & 1.71 & 1.72 & 1.69 & 1.70 & 0.09 & 0.96 \\
\hline $3.5 \% \mathrm{FCM}^{2}(\mathrm{~kg} / \mathrm{d})$ & 30.9 & 31.5 & 30.7 & 31.5 & 2.1 & 0.72 \\
\hline $\mathrm{ECM}^{3}(\mathrm{~kg} / \mathrm{d})$ & 32.6 & 33.1 & 32.2 & 32.9 & 2.1 & 0.77 \\
\hline ECM/DMI & 1.46 & 1.51 & 1.47 & 1.45 & 0.05 & 0.53 \\
\hline BW change $(\mathrm{kg} / 21 \mathrm{~d})$ & -3.0 & 10.6 & 3.7 & 2.8 & 3.5 & 0.12 \\
\hline
\end{tabular}

${ }^{1} \mathrm{CON}=$ control; $\mathrm{MOL}=4.4 \%$ molasses replacing corn; $\mathrm{MS} 3=2.9 \%$ molasses product replacing corn; MS6 $=$ $5.8 \%$ molasses product replacing corn.

${ }^{2} \mathrm{FCM}=(0.432 \times$ milk yield $)+(16.216 \times$ fat yield $)($ Dairy Records Management Systems, 2013)

${ }^{3} \mathrm{ECM}=(0.327 \times$ milk yield $)+(12.86 \times$ fat yield $)+(7.65 \times$ protein yield $)($ Dairy Records Management Systems, 2013). 
Table 4. Effects of treatments on classes of milk FA

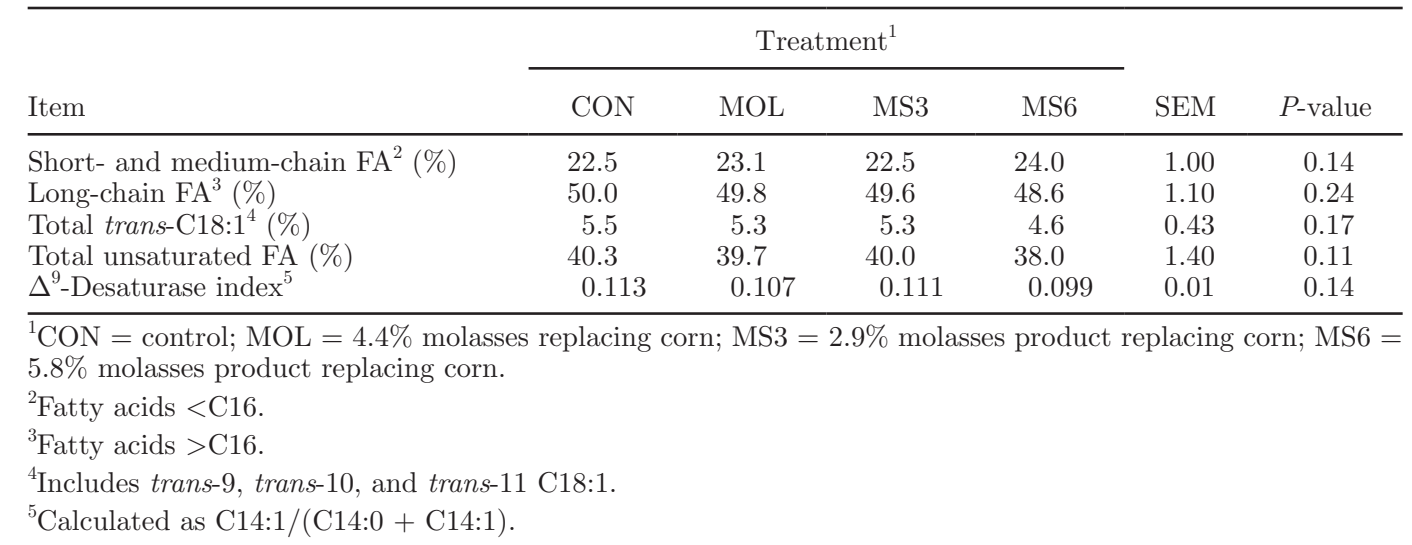

ments, with the exception of starch content, but this was by design. Estimated $\mathrm{NE}_{\mathrm{L}}$ content remained similar across treatments.

On average, animals consumed $22.2 \pm 1.1 \mathrm{~kg}$ of $\mathrm{DM} / \mathrm{d}$ (Table 3 ) and produced $34.6 \pm 1.8 \mathrm{~kg}$ of milk/d, but none of the treatments altered these variables. The lack of responses for DMI and milk production are in agreement with observations by Mullins and Brad- ford (2010) when they used molasses in combination with whole cottonseed in rations for lactating cattle. Another study, however, reported that supplemental liquid feeds augmented DMI of lactating cows by 1.4 $\mathrm{kg} / \mathrm{d}$ and tended to increase milk production (DeVries and Gill, 2012). Cows in the DeVries and Gill (2012) study averaged 88 DIM, whereas cows in the current study averaged 196 DIM. Firkins et al. (2008) demon-
A

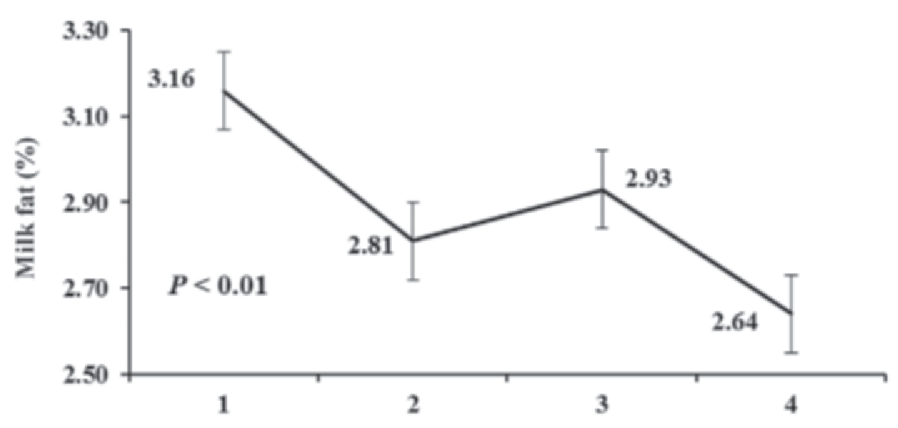

C

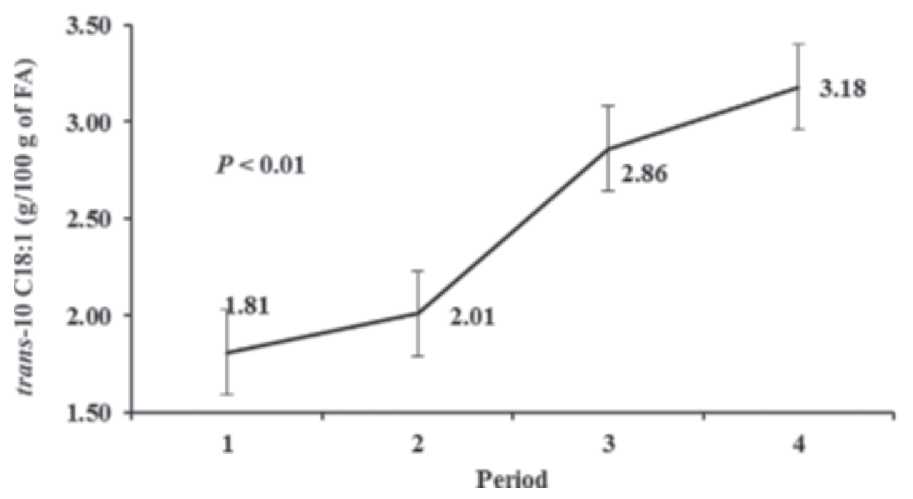

B

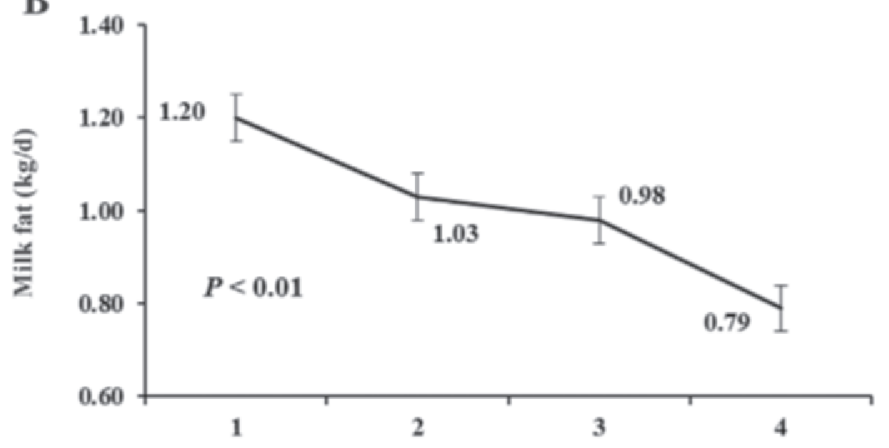

D

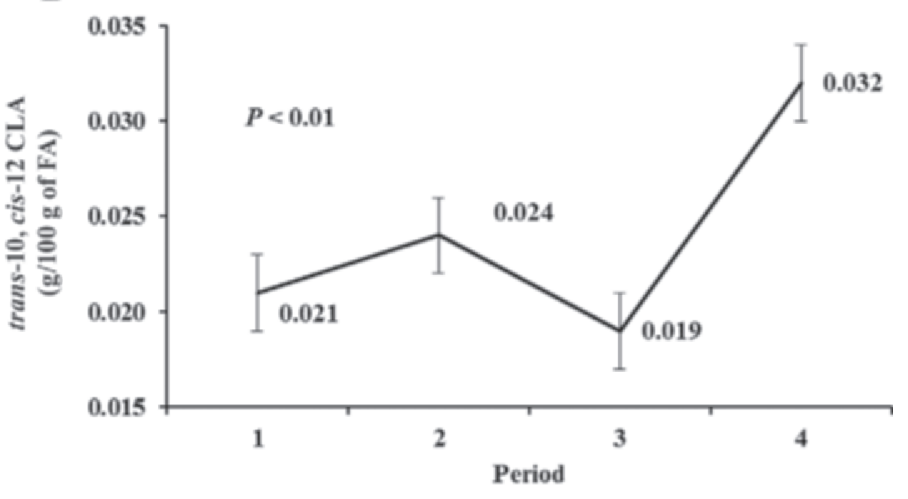

Figure 1. Effect of period on milk fat yield and milk fat content. Fixed effects of period were evaluated for (A) milk fat concentration, (B) milk fat yield, (C) trans-10 C18:1 concentration, and (D) trans-10,cis-12 CLA concentration. Periods lasted 21 d, with measurements taken in the final $4 \mathrm{~d}$ of each period. The effect of period is noted on each panel; period $\times$ treatment interactions were not significant. Values are LSM $\pm \operatorname{SEM}(\mathrm{n}=8$ pens $)$. 
Table 5. Effects of treatments on milk FA profile

\begin{tabular}{|c|c|c|c|c|c|c|}
\hline \multirow{2}{*}{$\begin{array}{l}\text { FA } \\
(\mathrm{g} / 100 \mathrm{~g} \text { of } \mathrm{FA})\end{array}$} & \multicolumn{4}{|c|}{ Treatment $^{1}$} & \multirow[b]{2}{*}{ SEM } & \multirow[b]{2}{*}{$P$-value } \\
\hline & $\mathrm{CON}$ & MOL & MS3 & MS6 & & \\
\hline C4:0 & 1.83 & 1.93 & 1.91 & 2.09 & 0.12 & 0.09 \\
\hline C6:0 & 1.46 & 1.57 & 1.55 & 1.72 & 0.15 & 0.06 \\
\hline C8:0 & 1.02 & 1.04 & 0.97 & 1.12 & 0.11 & 0.10 \\
\hline C10:0 & 2.32 & 2.5 & 2.36 & 2.68 & 0.22 & 0.13 \\
\hline C11:0 & 0.084 & 0.074 & 0.071 & 0.077 & 0.011 & 0.48 \\
\hline C12:0 & 3.04 & 3.18 & 3.02 & 3.32 & 0.2 & 0.16 \\
\hline C14:0 & 10.36 & 10.5 & 10.32 & 10.8 & 0.31 & 0.29 \\
\hline C14:1 & 1.29 & 1.22 & 1.27 & 1.16 & 0.06 & 0.14 \\
\hline C15:0 & 1.11 & 1.08 & 1.07 & 1.08 & 0.04 & 0.38 \\
\hline C16:0 & 25.35 & 25.09 & 25.71 & 25.47 & 0.27 & 0.35 \\
\hline C16:1 & 1.93 & 1.84 & 1.95 & 1.67 & 0.16 & 0.21 \\
\hline C17:0 & 0.87 & 0.88 & 0.85 & 0.87 & 0.12 & 0.26 \\
\hline $\mathrm{C} 18: 0$ & $11.75^{\mathrm{b}}$ & $12.00^{\mathrm{ab}}$ & $11.69^{\mathrm{b}}$ & $12.27^{\mathrm{a}}$ & 0.29 & 0.02 \\
\hline trans-9 C18:1 & 0.526 & 0.516 & 0.500 & 0.474 & 0.031 & 0.19 \\
\hline trans-10 C18:1 & 2.92 & 2.57 & 2.46 & 1.91 & 0.42 & $<0.10$ \\
\hline trans-11 C18:1 & 2.03 & 2.25 & 2.34 & 2.16 & 0.17 & 0.18 \\
\hline cis-9 C18:1 & 23.44 & 23.11 & 23.36 & 22.76 & 0.78 & 0.14 \\
\hline cis-11 C18:1 & 0.79 & 0.76 & 0.76 & 0.73 & 0.04 & 0.37 \\
\hline trans C18:2n-6 & 0.026 & 0.024 & 0.025 & 0.019 & 0.005 & 0.83 \\
\hline cis $\mathrm{C} 18: 2 \mathrm{n}-6$ & 5.13 & 5.11 & 5.04 & 4.92 & 0.17 & 0.33 \\
\hline cis-9,trans-11 CLA & 1.10 & 1.12 & 1.20 & 1.07 & 0.08 & 0.26 \\
\hline trans-10,cis-12 CLA & 0.025 & 0.026 & 0.026 & 0.019 & 0.004 & 0.16 \\
\hline cis-9,cis-11 CLA & 0.013 & 0.014 & 0.015 & 0.015 & 0.004 & 0.72 \\
\hline trans-9,trans-11 CLA & 0.087 & 0.083 & 0.086 & 0.076 & 0.006 & 0.31 \\
\hline C18:3n-6 & 0.045 & 0.049 & 0.045 & 0.049 & 0.003 & 0.09 \\
\hline C18:3n-3 & 0.416 & 0.407 & 0.397 & 0.469 & 0.013 & 0.69 \\
\hline C20:0 & 0.160 & 0.162 & 0.158 & 0.167 & 0.004 & 0.06 \\
\hline C20:1 & 0.068 & 0.068 & 0.070 & 0.065 & 0.003 & 0.47 \\
\hline C20:2 & 0.055 & 0.057 & 0.057 & 0.054 & 0.004 & 0.84 \\
\hline C20:3n-6 & 0.186 & 0.192 & 0.178 & 0.188 & 0.013 & 0.29 \\
\hline $\mathrm{C} 20: 4 n-6$ & 0.213 & 0.216 & 0.207 & 0.219 & 0.011 & 0.14 \\
\hline C20:5n-3 & 0.022 & 0.025 & 0.024 & 0.025 & 0.005 & 0.67 \\
\hline $\mathrm{C} 22: 0$ & 0.059 & 0.059 & 0.055 & 0.059 & 0.006 & 0.93 \\
\hline $\mathrm{C} 23: 0$ & 0.012 & 0.016 & 0.014 & 0.014 & 0.004 & 0.16 \\
\hline C24:0 & 0.016 & 0.026 & 0.027 & 0.028 & 0.004 & 0.17 \\
\hline
\end{tabular}

${ }^{a, b}$ Values within a row that do not share a common superscript letter are significantly different.

${ }^{1} \mathrm{CON}=$ control; $\mathrm{MOL}=4.4 \%$ molasses replacing corn; $\mathrm{MS} 3=2.9 \%$ molasses product replacing corn; MS6 = $5.8 \%$ molasses product replacing corn.

strated increased milk fat and ECM production when the same molasses-based liquid feed used in the current study was provided at $3.3 \%$ of diet DM in a $38 \%$ NFC diet, beginning at 77 DIM. Other studies have noted increased DMI and milk fat production when sucrose, the primary sugar in cane molasses, replaced corn grain in diets for early-lactation cows (Broderick et al., 2008; Penner and Oba, 2009). Empirical results, therefore, suggest that early- to mid-lactation cows may be more responsive to replacement of starch with dietary sugar, although the potential mechanisms underlying a differential response are unclear.

In a previous study, milk fat content significantly increased when molasses replaced corn at $5.0 \%$ of DM (Martel et al., 2011). Under the conditions of this experiment, treatments did not alter milk fat concentration or yield compared with the control, but both milk fat percentage and yield decreased over the course of the experiment (Figure 1). This decrease corresponded to increasing concentrations of trans-10 $\mathrm{C} 18: 1$ and trans10, cis-12 CLA (Figure 1, panels C and D), both FA isomers associated with MFD (Harvatine et al., 2009; Shingfield et al., 2009). Recent studies have reported progressive decreases in milk fat content for 11 to $21 \mathrm{~d}$ after an MFD-inducing diet is fed (He et al., 2012; Rico and Harvatine, 2013), but we are unaware of evidence that such responses extend for months. The progressive exacerbation of MFD is often attributed to adaptation of the rumen microbial population leading to a shift in ruminal metabolism, especially in biohydrogenation. The continuing decline in milk fat content over 3 mo may be partially explained by the fact that as cows move into late lactation, they become more susceptible to diet-induced MFD (Bradford and Allen, 2004). It is also possible that, as environmental temperatures increased during the study, rancidity of fat sources (i.e., 
DDGS) became a progressively larger problem. Although no conclusive explanation for the lack of effects on milk fat can be determined, the primary mechanism driving MFD across treatments in this study was likely the combination of relatively high starch content and abundant rumen-available unsaturated FA from DDGS (Ranathunga et al., 2010). The higher dietary starch content (33-36\%) of the diets fed by Martel et al. (2011) may explain the partial alleviation of MFD by molasses in that scenario compared with the present study.

Milk FA classes of interest are detailed in Table 4, and Table 5 lists individual FA concentrations. Treatments did not alter the proportions of short versus long-chain FA, saturated versus unsaturated FA, or total trans FA proportions. The concentration of stearic acid (C18:0) in milk from animals that consumed the MS6 diet was higher than that from animals that consumed CON and MS3 diets, but no other significant effects on individual FA were observed. The concentration of trans-10 C18:1 tended to decrease in MS6 versus CON diets, and some short-chain FA (C4:0 and C6:0) tended to increase for the MS6 diet compared with the CON diet. Effects on these $4 \mathrm{FA}$ are consistent with our previous observations (Martel et al., 2011), but in this case, the magnitude of responses was less and did not translate into increased milk fat yield with molasses treatments.

In conclusion, exchanging molasses-based products for corn at 2.9 to $5.8 \%$ of dietary DM did not influence productivity and had few effects on the milk FA profile. Therefore, if molasses enhances ruminal FA biohydrogenation, the effect in this study was minor.

\section{ACKNOWLEDGMENTS}

This study was funded in part by Quality Liquid Feeds (Dodgeville, WI). The authors gratefully acknowledge the valuable comments from Lisa Davis (Dodgeville, WI).

\section{REFERENCES}

AOAC International. 2000. Official Methods of Analysis. 17th ed. AOAC International, Arlington, VA.

Bradford, B. J., and M. S. Allen. 2004. Milk fat responses to a change in diet fermentability vary by production level in dairy cattle. J. Dairy Sci. 87:3800-3807.

Broderick, G. A., N. D. Luchini, S. M. Reynal, G. A. Varga, and V. A. Ishler. 2008. Effect on production of replacing dietary starch with sucrose in lactating dairy cows. J. Dairy Sci. 91:4801-4810.

Dairy Records Management Systems. 2013. DHI glossary. Accessed Jun. 17, 2013. http://www.drms.org/PDF/materials/glossary.pdf.

DeVries, T. J., and R. M. Gill. 2012. Adding liquid feed to a total mixed ration reduces feed sorting behavior and improves productivity of lactating dairy cows. J. Dairy Sci. 95:2648-2655.
Firkins, J. L., B. S. Oldick, J. Pantoja, C. Reveneau, L. E. Gilligan, and L. Carver. 2008. Efficacy of liquid feeds varying in concentration and composition of fat, nonprotein nitrogen, and nonfiber carbohydrates for lactating cows. J. Dairy Sci. 91:1969-1984.

Getachew, G., P. H. Robinson, E. P. DePeters, and S. J. Taylor. 2004 Relationship between chemical composition, dry matter degradation and in vitro gas production of several ruminant feeds. Anim. Feed Sci. Technol. 11:57-71.

Harvatine, K. J., Y. R. Boisclair, and D. E. Bauman. 2009. Recent advances in the regulation of milk fat synthesis. Animal 3:40-54.

He, M., K. L. Perfield, H. B. Green, and L. E. Armentano. 2012. Effect of dietary fat blend enriched in oleic or linoleic acid and monensin supplementation on dairy cattle performance, milk fatty acid profiles, and milk fat depression. J. Dairy Sci. 95:1447-1461.

Hollmann, M., M. S. Allen, and D. K. Beede. 2011. Diet fermentability influences lactational performance responses to corn distillers grains: A meta-analysis. J. Dairy Sci. 94:2007-2021.

Janicek, B. N., P. J. Kononoff, A. M. Gehman, and P. H. Doane. 2008. The effect of feeding dried distillers grains plus solubles on milk production and excretion of urinary purine derivatives. J. Dairy Sci. 91:3544-3553.

Kleinschmit, D. H., D. J. Schingoethe, K. F. Kalscheur, and A. R. Hippen. 2006. Evaluation of various sources of corn dried distillers grains plus solubles for lactating dairy cattle. J. Dairy Sci. 89:4784-4794.

Lane, J. H., and L. Eynon. 1923. Determination of reducing sugars by means of Fehling's solution with methylene blue as internal indicator. J. Soc. Chem. Ind. 42:32T-37T.

Martel, C. A., E. C. Titgemeyer, L. K. Mamedova, and B. J. Bradford. 2011. Dietary molasses increases ruminal $\mathrm{pH}$ and enhances ruminal biohydrogenation during milk fat depression. J. Dairy Sci. 94:3995-4004.

Mullins, C. R., and B. J. Bradford. 2010. Effects of a molasses-coated cottonseed product on diet digestibility, performance, and milk fatty acid profile of lactating dairy cattle. J. Dairy Sci. 93:31283135 .

NRC. 2001. Nutrient Requirements of Dairy Cattle. 7th rev. ed. National Academies Press, Washington, DC.

Penner, G. B., and M. Oba. 2009. Increasing dietary sugar concentration may improve dry matter intake, ruminal fermentation, and productivity of dairy cows in the postpartum phase of the transition period. J. Dairy Sci. 92:3341-3353.

Powers, W. J., H. H. van Horn, B. Harris Jr., and C. J. Wilcox. 1995. Effects of variable sources of distillers dried grains plus solubles on milk yield and composition. J. Dairy Sci. 78:388-396.

Ranathunga, S. D., K. F. Kalscheur, A. R. Hippen, and D. J. Schingoethe. 2010. Replacement of starch from corn with nonforage fiber from distillers grains and soyhulls in diets of lactating dairy cows. J. Dairy Sci. 93:1086-1097.

Rico, D. E., and K. J. Harvatine. 2013. Induction of and recovery from milk fat depression occurs progressively in dairy cows switched between diets that differ in fiber and oil concentration. J. Dairy Sci. 96:6621-6630.

Santos, F. A. P., J. E. P. Santos, C. B. Theurer, and J. T. Huber. 1998. Effects of rumen-undegradable protein on dairy cow performance: A 12-year literature review. J. Dairy Sci. 81:3182-3213.

Sasikala-Appukuttan, A. K., D. J. Schingoethe, A. R. Hippen, K. F. Kalscheur, K. Karges, and M. L. Gibson. 2008. The feeding value of corn distillers solubles for lactating dairy cows. J. Dairy Sci. 91:279-287.

Shingfield, K. J., A. Sæbø, P.-C. Sæbø, V. Toivonen, and J. M. Griinari. 2009. Effect of abomasal infusions of a mixture of octadecenoic acids on milk fat synthesis in lactating cows. J. Dairy Sci. 92:4317-4329.

Van Soest, P. J., J. B. Robertson, and B. A. Lewis. 1991. Methods for dietary fiber, neutral detergent fiber, and nonstarch polysaccharides in relation to animal nutrition. J. Dairy Sci. 74:3583-3597. 